\title{
METODE TRANSPROGRAMMING DALAM PERANCANGAN RUANG BERHUNI TERPADU KOMUNITAS UKM ROTAN DI GROGOL
}

\author{
Christine Priscilla ${ }^{1)}$, Diah Anggraini ${ }^{2)}$ \\ 1)Program Studi S1 Arsitektur, Fakultas Teknik, Universitas Tarumanagara, christine.priscilla@hotmail.com \\ 2)Program Studi S1 Arsitektur, Fakultas Teknik, Universitas Tarumanagara, diah_ismono@yahoo.com
}

\begin{abstract}
Abstrak
Pandemi Covid-19 berdampak terhadap berbagai sektor, salah satunya sektor ekonomi. Sektor perekonomian di Indonesia mengalami kontraksi pertumbuhan ekonomi kuartal III/2020, sebesar 3,49 persen. Kemerosotan ekonomi tersebut tidak hanya berdampak pada kegiatan perusahaan-perusahaan besar, namun juga sangat berdampak bagi para pelaku usaha kecil, seperti komunitas penggiat Usaha Kecil dan Menengah (UKM) yang turut andil dalam perekonomian daerah. Satu dari sekian banyak komunitas UKM yang terdampak pandemi Covid-19 yaitu komunitas UKM Rotan Semeru-Grogol, yang merupakan sentra UKM pengrajin rotan di Jakarta Barat. Permasalahan yang terjadi bukan hanya penurunan pemasukan maupun kekhawatiran pembeli melakukan transaksi fisik, namun bagaimana agar komunitas tetap dapat bertahan dan berkembang dalam situasi tidak terduga. Persaingan UKM dengan usaha lain seperti startup dan e-commerce di ranah teknologi dan ruang/media non-fisik menjadi perhatian dalam membentuk ruang berhuni bagi komunitas UKM, khususnya UKM Rotan Semeru di masa mendatang. Studi ini bertujuan menghasilkan suatu konsep berhuni terpadu yang dapat mewadahi ruang tinggal sekaligus menjadi tempat produksi, pengembangan produk dan pemasaran hasil kerajinan rotan. Mengingat kompleksitas program memadukan ruang berhuni dengan proses kreatif dan ruang ekonomi berbasis teknologi, maka dalam proses perancangan digunakan metode Transprogramming yang mengkombinasikan aspek lokalitas dan teknologi dalam keseharian berhuni. Sehingga hasil perancangan bukan hanya ruang komersil ataupun ruang kerja, namun juga ruang tinggal para pengrajin. Aspek lokalitas dipertahankan melalui unsur material, adanya ruang produksi manual, kehidupan bertetangga, dan bersosialisasi. Begitu pula dengan aspek teknologi pada bangunan menghasilkan ruang komersil yang moderen, yaitu kios-kios berupa windows shopping, proses jual beli drive-thru dan secara daring. Dapat disimpulkan bahwa kombinasi aspek dan program pada perancangan hunian terpadu UKM rotan membentuk ruang berhuni di masa depan yang mensejahterakan anggota komunitasnya.
\end{abstract}

Kata kunci: Covid-19; lokalitas; ruang berhuni; UKM Rotan

\begin{abstract}
The Covid-19 pandemic has impacted on any sectors, economic is one of the worst affected sector. In 2020, Indonesia's economic growth in third quarter (Q3/2020), shrink by 3,49\%. The economic deterioration is not only impact the big companies but also impacted on small business communities, such as the UKM (Usaha Kecil dan Menengah) that contribute the revenue of local government. One of much UKM that affected by the pandemic is UKM Rotan Semeru community, the central of UKM rattan in Jakarta Barat. The problem is not only the lower-income individuals or their concern about physical interactions but how the communities could survive and evolve in an unexpected situation. The competition between UKM with start-up and e-commerce on the realm of technology, internet, online media is a concern to form the future dwelling space for UKM community, especially UKM Rotan Semeru. The purpose of this study is to produce an integrated dwelling's concept that could provide a place for live, producing, product's develop, and marketing. Remember the program complexity integrates dwelling with creative process and technology based economic space, so trans-programming method was used to combining the locality and
\end{abstract}


technology aspect. The result of design not only for commercial or working space but also residence. There are material's element, manual production room, neighbors, and social activities to maintain the locality aspect. And then the technology on building shows up by the modern commercial spaces, windows shopping, drive-thru, and online shopping. The conclusion is the aspects and programs combination from the integrated dwelling of UKM Rotan's design formed a future dwelling that bring a prosperity to their community.

Keywords: The Covid-19; locality; dwelling; UKM Rotan

\section{PENDAHULUAN}

\section{Latar Belakang}

Wabah virus Corona (Covid-19) yang sedang melanda seluruh belahan bumi, termasuk Indonesia, menimbulkan keresahan di tengah masyarakat. Virus ini dinyatakan Pandemi oleh World Health Organization (WHO) pada pertengahan bulan Maret, 2020. Selain menimbulkan kecemasan, pandemi Covid-19 juga berdampak (merugikan) pada berbagai bidang dan sektor kegiatan berhuni masyarakat, seperti: kesehatan, perekonomian, infrastruktur, dan lain sebagainya.

Salah satunya terjadi di DKI Jakarta, kota yang saat ini berada di posisi pertama di Indonesia dengan kasus Covid-19 tertinggi. Di Ibukota, dampak yang merugikan pada sektor perekonomian ini sangat dirasakan oleh para pelaku Usaha Kecil dan Menengah (UKM). Adanya Pembatasan Sosial Berskala Besar (PSBB) menghalangi gerak usaha para UKM yang kebanyakan berinteraksi secara fisik.

Lokasi yang dipilih untuk studi perancangan ini adalah UKM di Lokasi Sementara (Loksem) Rotan Semeru, Grogol, Jakarta Barat, dengan berkuranganya pembeli karena dalam situasi pandemi perdagangan secara daring lebih diminati. Para pelaku aktif saat ini adalah generasi pertama belum terbiasa memanfaatkan teknologi IT dan media sosial. Sementara generasi mudanya, semakin terlatih, sebagai dampak positif dari keharusan sekolah/kuliah daring seperti situasi pandemi saat ini.

Maka rencana perancangan ruang berhuni yang memiliki konsep tinggi inovasi yang adaptif, tangguh dan berkelanjutan diperlukan sebagai jawaban dari permasalahan yang ada. Adapun proyek akan fokus pada pertimbangan aspek ekonomi-teknologi-interaksi sosial dengan pendekatan teori lokalitas dan arsitektur keseharian agar dapat menjadi wadah kegiatan/ruang berhuni di masa depan yang tangguh.

\section{Rumusan Permasalahan}

Melalui peningkatan kemampuan pihak penggiat UKM Rotan terutama generasi muda atau penerusnya dapat memajukan usaha serta meningkatkan kesejahteraan komunitas UKM Rotan. Adanya konsep berhuni yang tepat bagi komunitas UKM Rotan juga dapat mendukung perubahan dari usaha konvensional menuju ke usaha kerajinan rotan yang moderen, sehingga mampu beradaptasi dan bersaing dalam perubahan situasi yang cepat di masa depan. Dengan desain hunian yang memadukan tempat tinggal sekaligus tempat produksi dan pengembangan usaha juga dapat mendukung proses berhuni komunitas UKM Rotan di masa depan.

\section{Tujuan}

Menghasilkan konsep perancangan dan desain bangunan hunian terpadu bagi penggiat UKM Rotan Semeru agar mampu menjadi komunitas yang tangguh dengan potensi lokalitas dan kesadaran teknologi agar siap serta mampu beradaptasi dan bersaing dalam mengatasi masalah saat ini dan di masa mendatang. 


\section{KAJIAN LITERATUR}

\section{Tentang Berhuni}

Berhuni memiliki definisi umum yaitu hidup di dalam atau pada sebuah tempat. Menurut Kamus Besar Bahasa Indonesia (KBBI), berhuni berarti ada yang menghuni; ada penghuninya. Sedangkan dalam bahasa Inggris kata 'berhuni' yaitu 'dwelling', berarti tempat tinggal/kediaman/rumah. Heidegger (1971) mengungkap kaitan antara berhuni, proses pembangunan dan konstruksi berpikir (building, dwelling, thinking). Heidegger juga menggunakan istilah dwelling sebagai sebuah konsep menghuni atau cara khas ada (dasein) di dunia untuk menetap, berkelana (to wander), dan bertahan hidup (to linger).

Secara arsitektural, tata ruang dalam berhuni memiliki ruang publik, servis, privat yang memperhatikan kenyamanan, keamanan, pencahayaan, pengudaraan, lingkungan kesehatan dan pendidikan, dan akses serta akomodasi yang layak untuk dihuni sesuai dengan status ekonomi seseorang ataupun kelompok orang. (Disarikan dari Jurnal "The Difference Between Dwelling and Home in Architecture" oleh Shadab Shidfar, 2013)

\section{Kegiatan Manusia dalam Berhuni}

Dari konsep berhuni yang ada, berbagai faktor menimbulkan beragam kegiatan manusia dalam berhuni. Menurut Christian Norberg-Schulz, berhuni adalah ruang di mana dapat bertemu orang lain untuk bertukar berbagai hal, mencapai kesepakatan dengan orang lain, dan memiliki dunia pilihan kita sendiri (dikutip dari kuliah tamu "The Future of Dwelling" oleh Veronica Gandha, 2020). Maka dapat disimpulkan bahwa kegiatan manusia dalam berhuni tidak melulu tinggal dan menetap dalam sebuah bangunan fisik, yaitu rumah, namun juga berupa interaksi/relasi sosial.

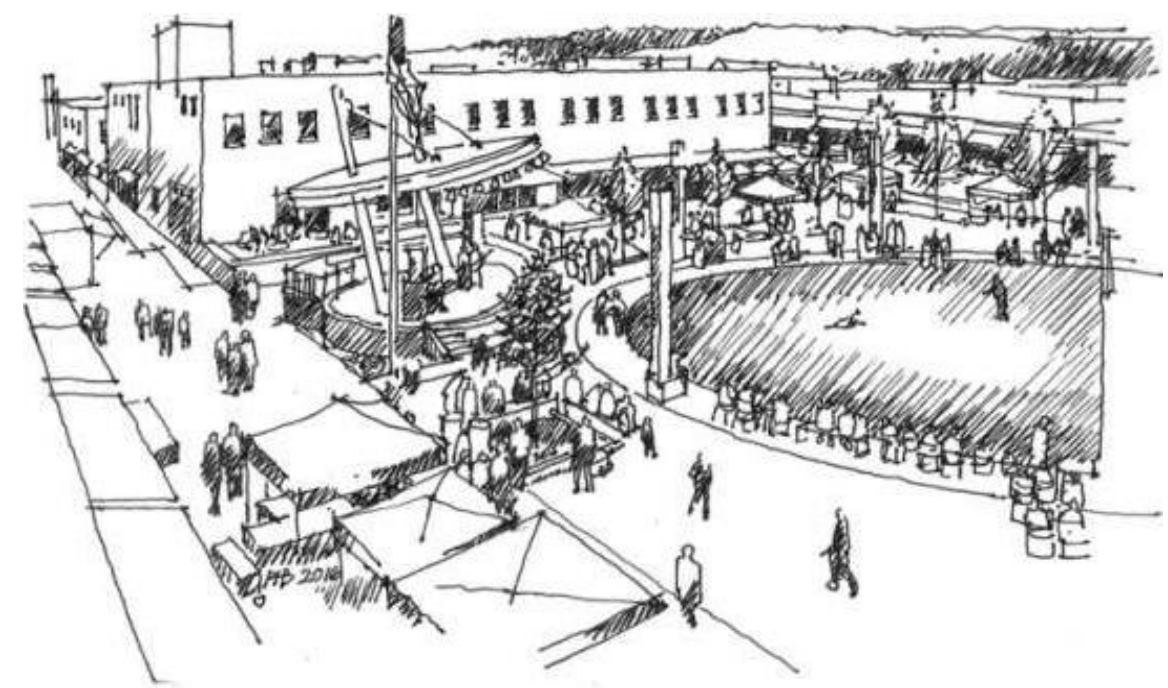

\section{Gambar 1. Sketsa Ruang Interaksi Sosial}

Sumber: Dakotafire Media oleh Paul H. Boerboom dan Jeremy Altman, AIA

Kegiatan manusia dalam berhuni dan makna berhuni itupun memiliki ciri: sesuatu yang berpola atau suatu ruang dengan fungsi tertentu digunakan secara rutin, berulang dalam jangka waktu tidak singkat oleh kelompok orang maupun individu yang memberikan kenyamanan, keamanan, rasa senang, dan lain sebagainya untuk bertahan hidup.

\section{Berhuni saat Pandemi Covid-19}

Virus Corona (Covid-19) pada 11 Maret 2020 dinyatakan oleh World Health Organization (WHO) sebagai pandemi, karena telah menyebar secara global. Hingga saat ini wabah Covid-19 belum terselesaikan karena kasusnya yang terus meningkat. 
Adanya pandemi Covid-19 ini sangat mengubah kehidupan, mulai dari gaya hidup, interaksi sosial, persepsi sehat, hingga mengubah konsep berhuni karena adanya pembatasan jarak bahkan peraturan oleh pemerintah di beberapa negara berupa social distancing, isolasi mandiri (self-isolation), maupun keputusan lockdown.

Melalui berbagai media digital, internet, televisi, hampir seluruh negara di dunia yang terinfeksi wabah Covid-19 melakukan pembatasan sosial, terbatasnya ruang gerak dalam melakukan setiap kegiatan, seperti adanya anjuran dari Centers for Disease Control and Prevention (CDC) untuk memiliki jarak aman setidaknya 2 meter ( 6 feet) saat berada di ruang publik maupun ketika berada di suatu ruang dengan orang lain. Hal tersebut membuat terbentuknya ruang individu yang menjaga jarak fisik, dapat dilihat seperti pada tata ruang restoran, kantor, pusat perbelanjaan hingga taman yang menyesuaikan.

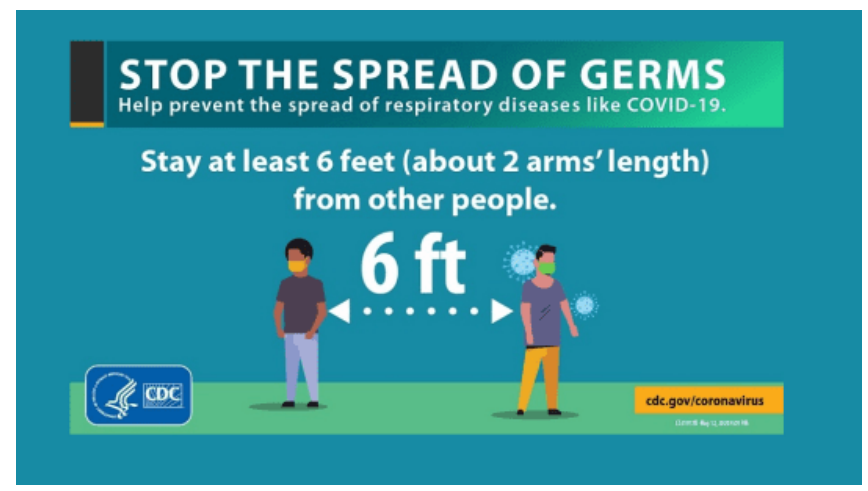

Gambar 2. Anjuran Jarak Aman saat Pandemi Covid-19 Sumber: Centers for Disease Control and Prevention (CDC)

Beberapa ahli melakukan riset dan prediksi terhadap ruang berhuni pasca Covid-19 secara arsitektural maupun non-arsitektural. Seperti prediksi arsitek Pallavi Dean (2020) dari Roar Studio, Dubai, mengatakan bahwa dalam konteks ini (Covid-19) desain yang cerdas, efisien dan fleksibel adalah suatu keharusan. Lain halnya dengan arsitek Sam Lubell (2020), disarikan dari webcast 'Design Disruption', menganggap bahwa pasca pandemi akan ada revolusi digital.

Kondisi berhuni saat pandemi dapat menjadi inovasi bahkan perubahan konsep berhuni pasca pandemi akibat pengalaman ruang yang telah dirasakan maupun yang telah menjadi kebiasaan. Maka dari itu penting pula untuk dipikirkan konsep berhuni berdasarkan kebutuhan kegiatan ekonomi, khususnya yang terdampak oleh pandemi Covid-19.

\section{Ruang Ekonomi saat Pandemi Covid-19}

Indonesia telah mengalami kontraksi pertumbuhan ekonomi, sebagaimana dapat dilihat pada Gambar 3. Menurut Badan Pusat Statistik (BPS) per akhir tahun 2020, pertumbuhan ekonomi kuartal III/2020 terkontraksi sebesar 3,49 persen.

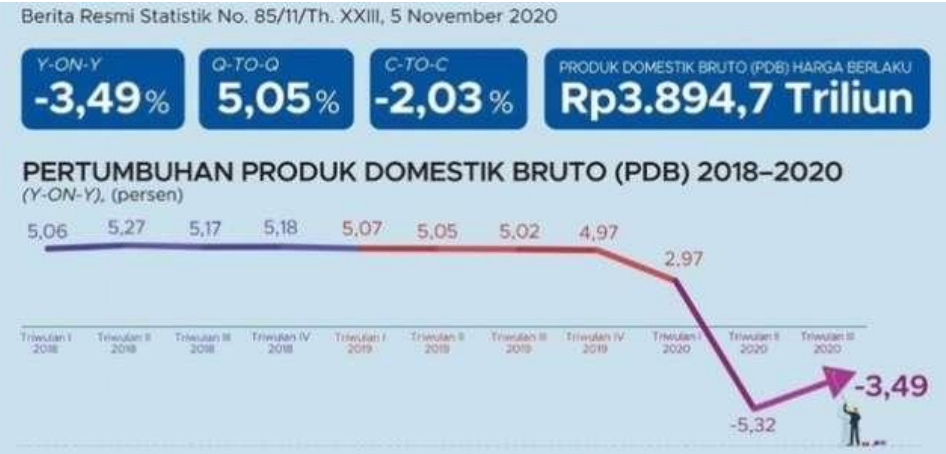

Gambar 3. Grafik Pertumbuhan Ekonomi Indonesia Triwulan III-2020 Sumber: Badan Pusat Statistik 
Kemerosotan ekonomi tersebut tidak hanya berdampak pada perusahaan-perusahaan besar namun juga bagi para pelaku usaha kecil, seperti Usaha Kecil dan Menengah (UKM). Ketertinggalan sistem kerja pelaku UKM yang gagap teknologi menyebabkan minimnya pemasukan, mengingat di masa pandemi mengharuskan lebih banyak di rumah dan jaga jarak yang kemudian mendorong kita cenderung memenuhi kebutuhan melalui belanja daring. Kurangnya edukasi dan adanya Pembatasan Sosial Berskala Besar (PSBB) di Jakarta sangat mengancam eksistensi dan sumber pemasukan UKM.

\section{Kegiatan Berhuni UKM saat Pandemi Covid-19}

Dalam kegiatan ekonomi suatu kelompok maupun individu, ruang berhuni seperti ruang kerja sangat dibutuhkan untuk melakukan kegiatan ekonomi tersebut. Namun karena adanya pandemi, banyak pabrik, kantor, pusat industri lainnya yang dapat memajukan perekonomian ditutup, karena meminimalisir adanya suatu kerumunan massal, kepadatan suatu ruang, dan jaga jarak.

Menurut Bambang PS Brodjonegoro (2020), Menteri Riset dan Teknologi, pada tulisannya "UMKM 4.0" yang dimuat Harian Kompas (halaman 6, 14 Agustus 2020), bahwa pada masa pandemi perlu dilakukan upaya untuk menghubungkan UMKM dengan calon pembeli karena "terputus" dengan konsumennya, sehingga akses dan literasi pelaku UMKM terhadap teknologi dibutuhkan mengingat sudah 97 persen dari wilayah Indonesia terjangkau e-dagang. Survei LIPI juga menunjukkan, UMKM yang melakukan transaksi secara daring lebih sedikit terkena dampak negatif terhadap ekonominya dibandingkan UMKM yang masih berjualan secara langsung. Pengembangan usaha pun dapat berjalan dengan memanfaatkan teknologi digital untuk pemasaran.

Adanya persaingan UKM dengan usaha-usaha seperti startup dan e-commerce selain di ranah teknologi, juga pada ruang/media non-fisik yang mendukung terutama di masa pandemi, maka kedepannya ruang berhuni bagi para UKM yang tepat diperlukan agar dapat terus bertahan dan bersaing, dengan melakukan penyetaraan, adaptasi dan kemajuan terhadap kejadian yang ada.

\section{METODE}

Studi ini menggabungkan beberapa pendekatan teoretis yaitu metode trans-programming, lokalitas dan keseharian. Disarikan dari Jurnal Theory of Contemporary Architecture, Bernard Tschumi oleh Architecture Podomoro University Batch 3, 2017, pada buku "Event Cities 3" (2005) Bernard Tschumi menyebutkan bahwa metode trans-programming mengkombinasikan dua program yang sifat dan konfigurasi spasialnya berbeda tanpa melihat kecocokannya, misalnya: perpustakaan dikombinasikan dengan arena balap (Novielle, 2007).

Pada studi dilakukan kombinasi dua konten sebagai pertimbangan dalam proses desain, yaitu lokalitas dan teknologi yang berlandaskan keseharian.

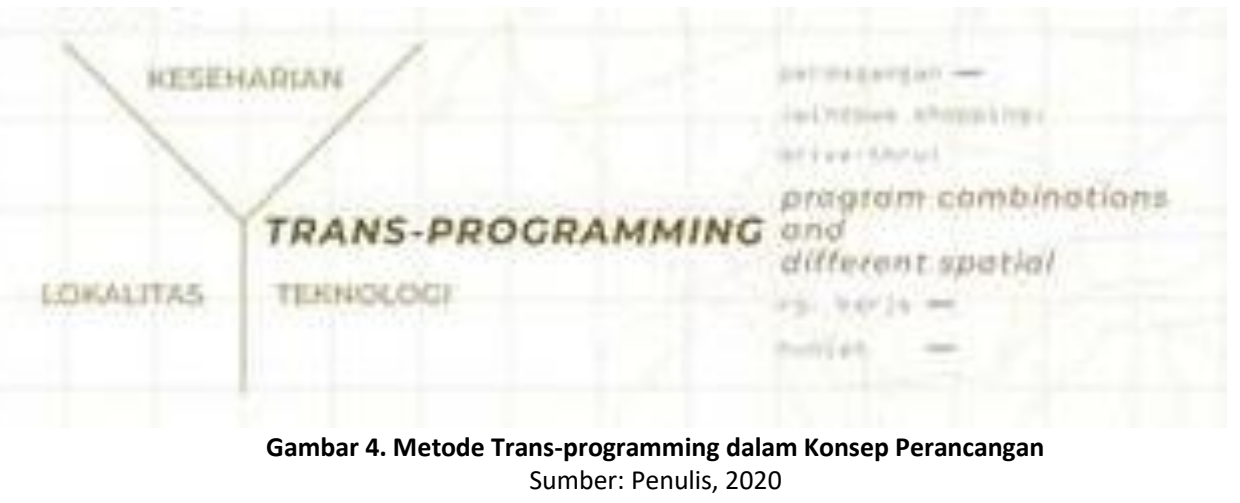


Studi ini menggunakan metode transprogramming yang diharapkan dapat memadukan konfigurasi beberapa kegiatan yang berbeda yaitu berhuni, produksi dan pengembangan produk serta usaha/pemasaran produk.

Lokalitas sebagai pendekatan desain merupakan sebuah gerakan yang memperjuangkan identitas kelokalan di tengah arus globalisasi. Pendekatan lokalitas merupakan sebuah cara berpikir dan bertindak yang mengutamakan aspek-aspek sejarah, tempat, teknologi, pengguna, dialog globalitas, identitas, tektonik-material, formasi sosial, dwelling, serta fenomena. Aspek metode ini dipilih karena seperti yang sedang dialami penggiat UKM Rotan Semeru, kegiatan lokalitas berupa produksi rotan yang saat ini berada di ambang kemerosotan ekonomi saat Pandemi Covid-19 sehingga memerlukan ruang untuk meningkatkan daya saing dalam inovasi kemajuan globalisasi, pengimbangan dunia teknologi.

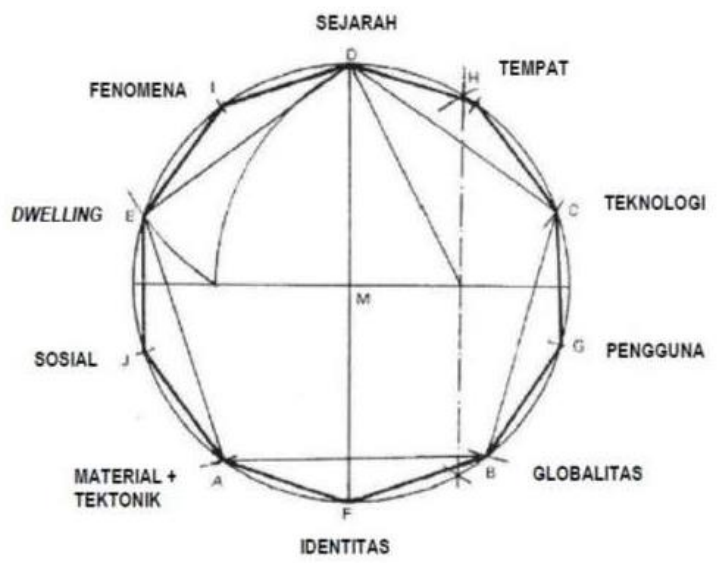

Gambar 5.Diagram Cara Berpikir dari Lokalitas

Sumber: Agustinus Sutanto (2020), Peta Metode Desain, hal.186

Pendekatan berikutnya adalah arsitektur keseharian (Henri Lefebvre, 1990-1991) yaitu sebuah respon sederhana yang langsung terhubung dengan kenyataan. Arsitektur keseharian tidak membangun melalui ide-ide abstrak, melainkan melihat kenyataan sebagai bahan referensi bertindak. Melalui sudut pandang keseharian, arsitektur menjadi usaha untuk melihat kenyataan tentang bagaimana manusia menggunakan ruang guna memenuhi kebutuhan hidupnya dan memunculkan ruang-ruang baru yang dibutuhkannya. Dengan berlandaskan keseharian arsitek harus memberikan kontribusi kepada masyarakat berdasarkan kebutuhan masyarakat yang benar terjadi.

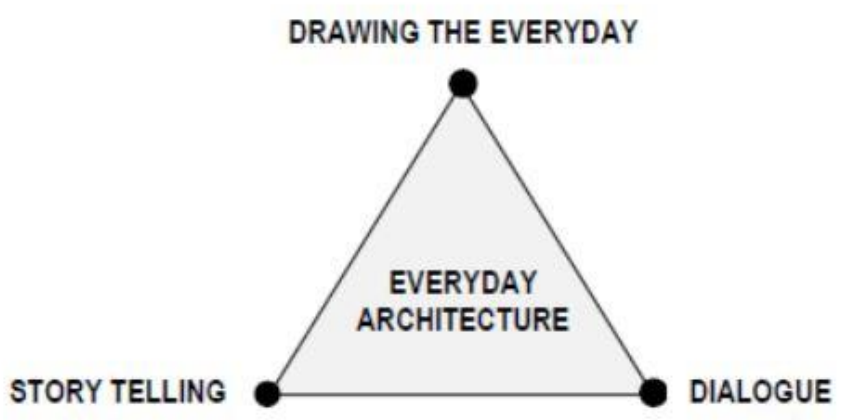

\section{Gambar 6. Diagram Taktik dan Strategi dalam Membaca Keseharian}

Sumber: Agustinus Sutanto (2020), Peta Metode Desain, hal.153

Berdasarkan keseharian, studi ini memperhatikan keseharian di kawasan UKM Rotan Semeru dalam mengidentifikasi berbagai kebutuhan komunitas dalam menjalani aktivitas sehari-hari, mencari solusi bagi persoalan yang dihadapi dan memahami harapan-harapan mereka di masa mendatang. 


\section{DISKUSI DAN HASIL}

Lokasi terpilih adalah kawasan UKM yang berada di bawah binaan Pemerintah Provinsi (Pemprov) DKI Jakarta, yang merupakan satu-satunya pusat kerajinan rotan di wilayah Jakarta Barat dan juga pusat kerajinan rotan terbesar di DKI Jakarta (Sumber: Portal Data Terpadu Pemprov DKI Jakarta, 2019). Pusat kerajinan rotan yang berada di Kecamatan Grogol Petamburan ini terkenal akan ciri khasnya dalam memproduksi beragam perabotan rumah tangga dengan masih menggunakan bahan rotan asli yang berasal dari beberapa pulau di Indonesia. Saat pandemi Covid-19 melanda dan pemerintah DKI Jakarta menerapkan Pembatasan Sosial Berskala Besar (PSBB), dampak dari sisi ekonomi sangat dirasakan oleh para penggiat UKM Rotan Semeru ini karena sepi pembeli, sehingga mengakibatkan turunnya angka penjualan dan diikuti dengan pengurangan produksi oleh para penggiat.
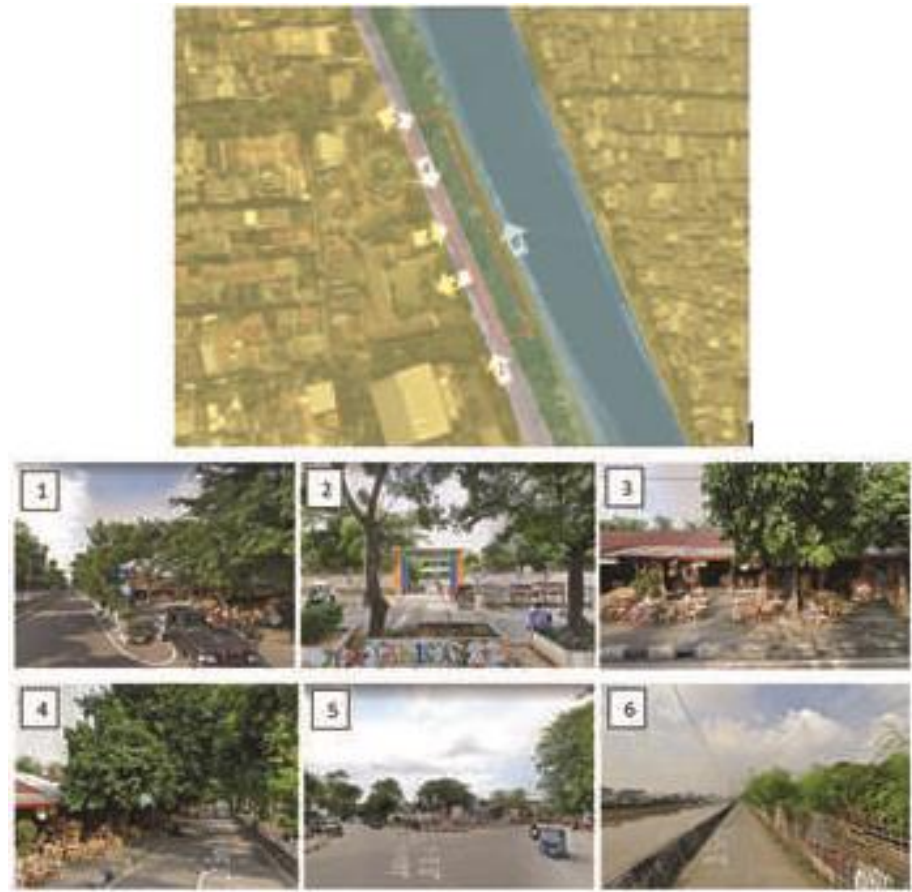

Gambar 7. Kondisi Eksisting Loksem UKM Rotan Semeru, Grogol

Sumber: Penulis, 2020

Mengingat lokasi eksisting UKM Rotan Semeru dinilai kurang strategis dan peruntukannya tidak sesuai, lihat Gambar 8, yaitu zona hijau: tidak boleh terbangun serta berstatus Loksem (lokasi sementara) maka melalui analisis awal disimpulkan bahwa untuk menjawab kebutuhan mereka, diperlukan suatu tapak yang memungkinkan UKM Rotan Semeru ini menghindari keterpurukan saat ini dan berhasil bangkit di masa depan.

Tapak baru berada di Jl. Prof. Dr. Latumenten, Grogol, Jakarta Barat berdasarkan analisis potensi yang ada, antara lain: dekat dengan pemukiman, berlokasi kurang dari 500m dari lokasi eksisting Loksem UKM Rotan Semeru, berada di jalan kolektor, merupakan zona perkantoran, perdagangan dan jasa, serta memiliki potensi untuk lebih menarik pengunjung/konsumen dari luar kawasan karena akses yang lebih mudah, dan dilalui oleh kendaraan umum (Transjakarta, angkot). Tapak juga berada dekat pusat keramaian area, yaitu Waduk Grogol yang kerap dijadikan tempat berkumpul dan bersantai oleh masyarakat sekitar. 


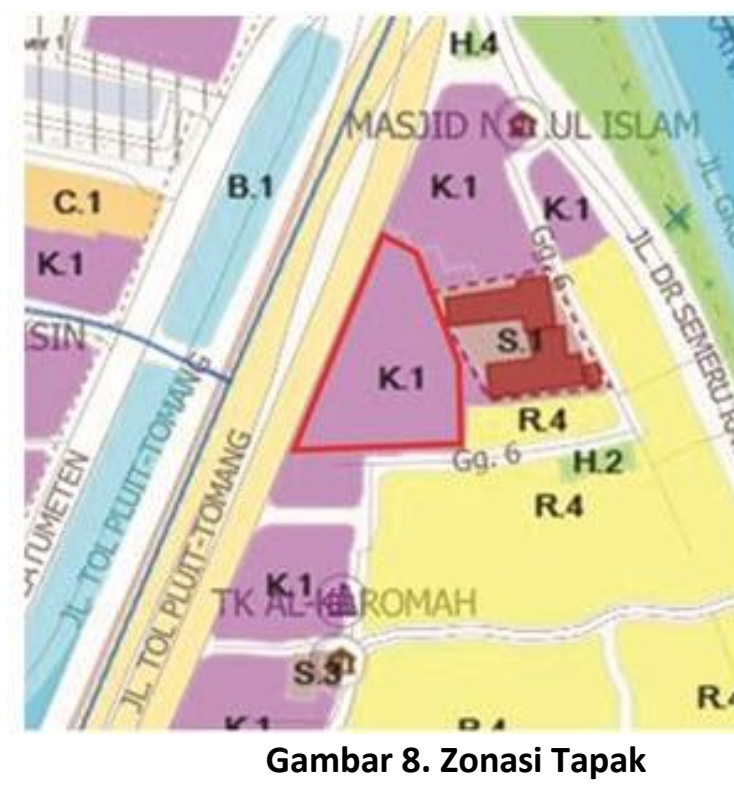

\begin{tabular}{ll} 
Peta Rencana Kota & \\
\hline KECAMATAN & GROGOL \\
PETAMBURAN & \\
KELURAHAN & GROGOL \\
KODE BLOK & 05 \\
SUB BLOK 001 & \\
SUB ZONA K.1 & \\
TPZ & \\
ID SUB BLOK & 001.K.1 \\
ZONA & Zona Perkantoran, \\
& Perdagangan dan Jasa \\
KDB & 60 \\
KLB & 2,4 \\
KB & 4 \\
KDH & 30 \\
KTB & 55 \\
TIPE & D
\end{tabular}

Sumber: Jakartasatu.jakarta.go.id

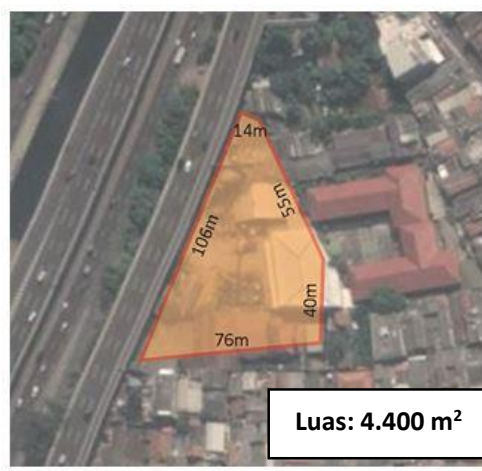

Gambar 9. Ukuran Tapak

Sumber: Jakartasatu.jakarta.go.id

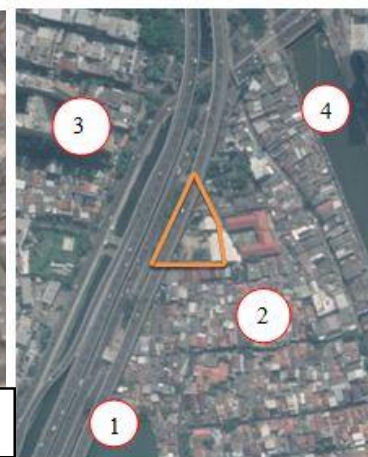

Gambar 10. Batas-batas pada Tapak Sumber: Google Earth

Batas Utara : Deretan Ruko

Batas Selatan: Pemukiman

Batas Timur : SDN Grogol 03 Pagi

Batas Barat : J1. Prof. Dr. Latumenten

Legenda

1. Waduk Grogol

2. Pemukiman

3. Apartemen Menara Latumenten

4. Sungai Ciliwung

Tapak terpilin

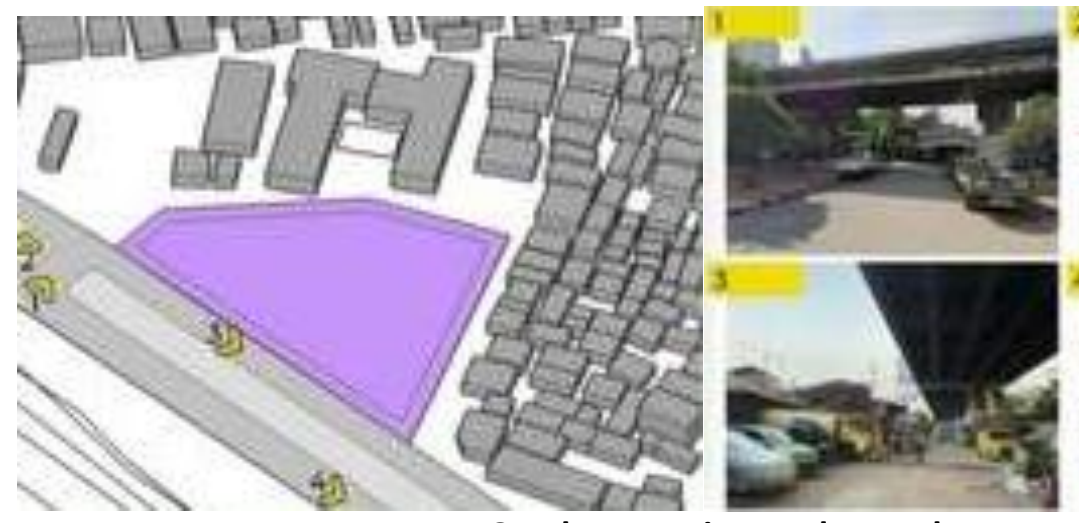

Gambar 11. View pada Tapak

Sumber: Penulis, 2020

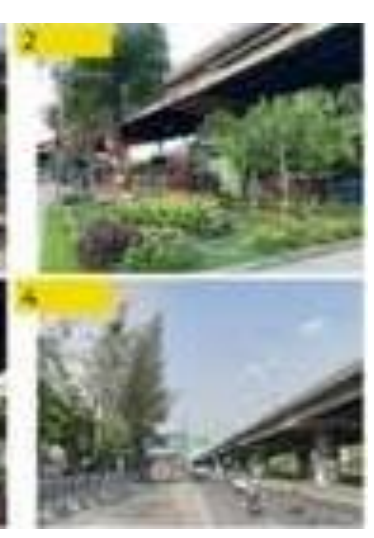




\section{Analisis SWOT}

Pada Tabel 1 dapat dilihat proses analisis SWOT untuk melihat kekuatan, kelemahan, peluang dan tantangan dari tapak terpilih.

Tabel 1. Strength, Weakness, Opportunity, Threat Lokasi Terpilih

\begin{tabular}{|c|c|c|c|}
\hline Strength & Weakness & Opportunity & Threat \\
\hline $\begin{array}{l}\text { - } \text { Satu-satunya pusat } \\
\text { kerajinan rotan di Jakarta } \\
\text { Barat } \\
\text { - } \\
\text { Akses mudah, berada di } \\
\text { jalan kolektor } \\
\text { - } \\
\text { - } \text { Deruntukan sesuai } \\
\text { - } \text { keramaian dengan pusat } \\
\text { - } \\
\text { - Dekat dengan pemukiman } \\
\text { Dilui publik transportasi }\end{array}$ & $\begin{array}{l}\text { - Tidak terkoneksi } \\
\text { langsung dengan } \\
\text { halte Transjakarta } \\
\text { hanya terkoneksi } \\
\text { dengan halte angkot } \\
\text { dan bus antar kota } \\
\text { - Kebisingan mobilitas } \\
\text { kendaraan }\end{array}$ & $\begin{array}{l}\text { - } \text { Mendukung } \\
\text { kegiatan } \\
\text { perekonomian } \\
\text { - } \text { Menjadi wadah } \\
\text { kegiatan UKM } \\
\text { beserta hunian } \\
\text { yang layak dan } \\
\text { sehat }\end{array}$ & $\begin{array}{l}\text { - Terhalang oleh } \\
\text { jalan layang, Jl. Tol } \\
\text { Pluit - Tomang }\end{array}$ \\
\hline
\end{tabular}

\section{Program Aktivitas dan Program Ruang}

\section{JUMLAH PENCHUNI}

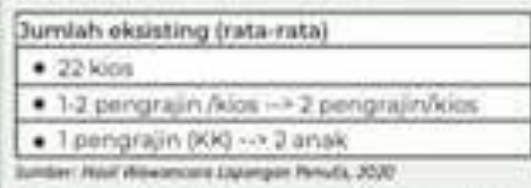

Perkiraan fumlah penerus (pengrajin)

2.2. kics $\times 2$ periggiat $\times 2$ anak $=100$ orang

iasumsilar hanya $50 \%$ yang malanjutkan

= 88 orang $\times 50^{\circ}=46$ orang (pengrajin)

Jumlah karyawan (asisten pengrajent)

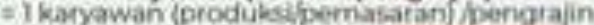

$=46$ pengrajin $\times 2$ katyawan $=$ ed karyawan

Perkiraan jumlah orang yang tingaal dil lokasi

346 periggiat + 3 angogota kevingar

Aasangan 2 anakVhopala $=46 \times 4=176$ orang

$(44 \mathrm{Kk})+$ Be karyawan $=264$ orang yang akan

bermukim di fokas

Gambar 12. Jumlah Penghuni

Sumber: Penulis, 2020

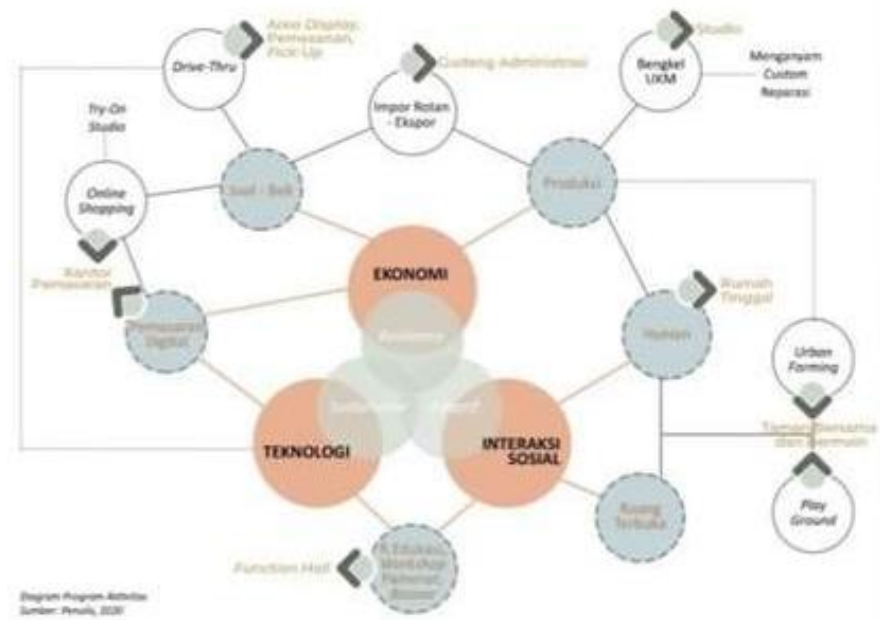

Gambar 13. Diagram Program Aktivitas dan Hubungan Ruang Sumber: Penulis, 2020 
Total luas lantai bangunan yaitu $10.368,7 \mathrm{~m} 2$. Luas tersebut terbagi atas lima lantai dan satu lantai atap dak. Lantai dasar memiliki luas $2.118 \mathrm{~m} 2$, lantai basemen $2.405,8 \mathrm{~m} 2$, lantai kedua $2.272,3 \mathrm{~m} 2$, lantai ketiga $2.164,3 \mathrm{~m} 2$, sedangkan lantai empat memiliki luas $1.408,3 \mathrm{~m} 2$.

Tabel 2. Program Ruang

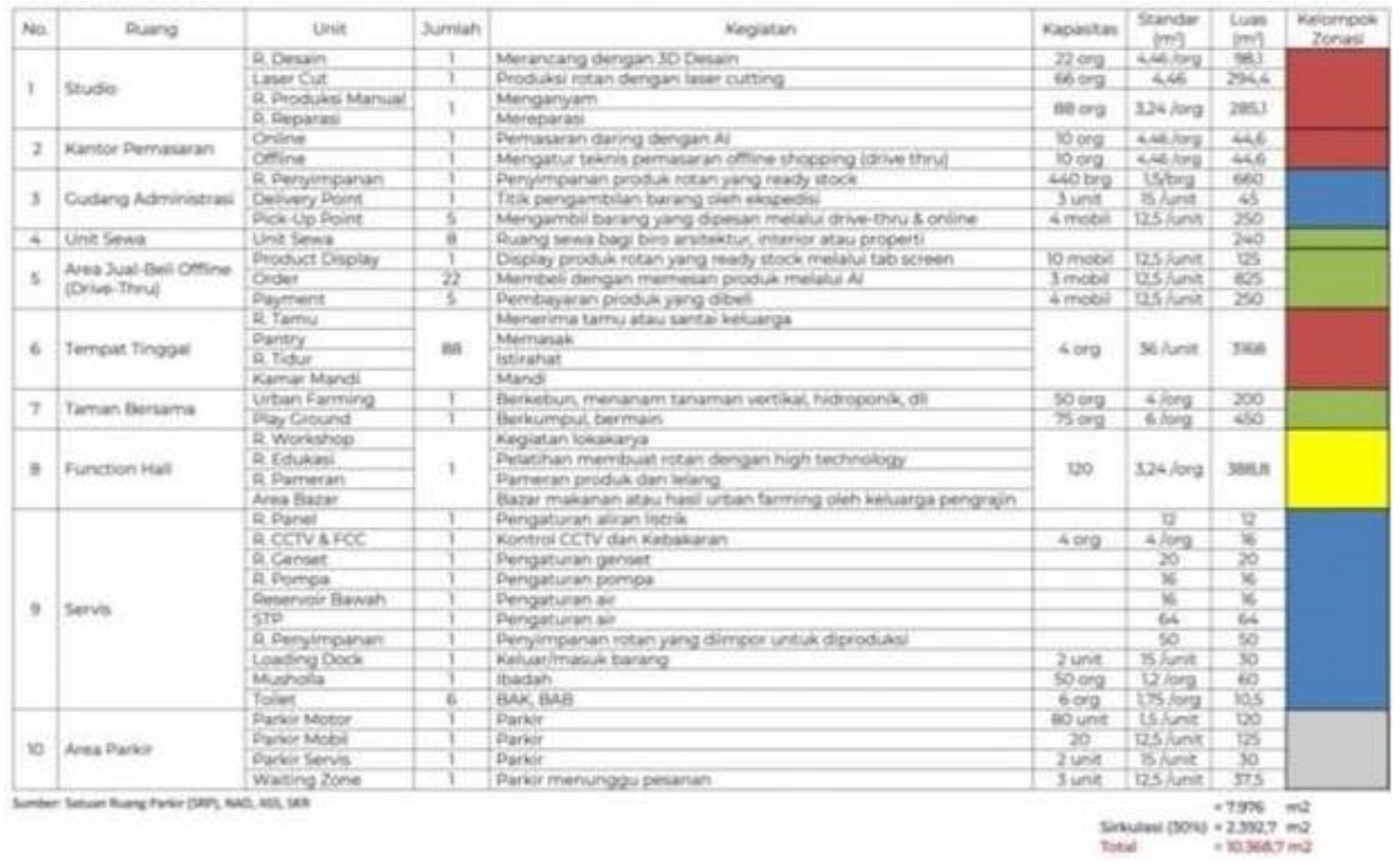

Sumber: Penulis 2020

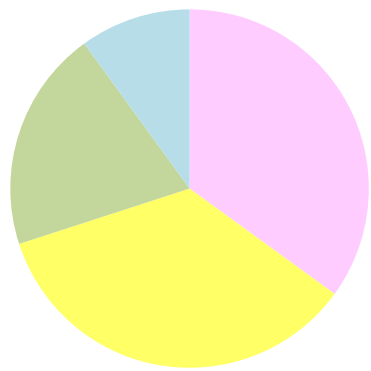

Ruang Kerja dan Komersil

Hunian

Public Space

Servis

Gambar 14. Diagram Presentasi Fungsi Ruang

Sumber: Penulis, 2020

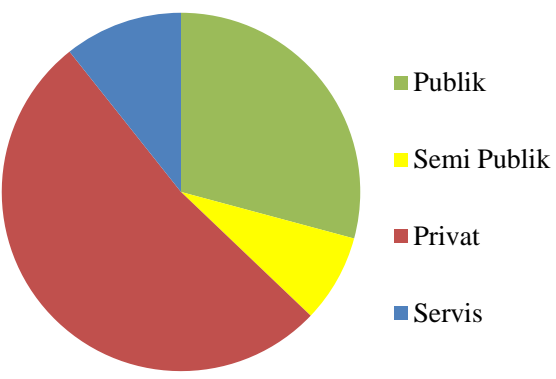

Gambar 15. Diagram Presentasi Zona Ruang

Sumber: Penulis, 2020 


\section{Analisis dan Konsep Sirkulasi dan Aksesibilitas}

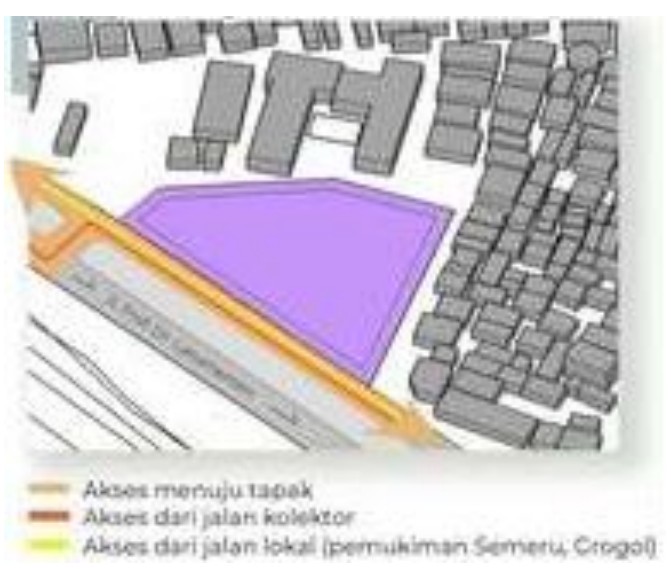

Gambar 16. Akses pada Tapak

Sumber: Penulis, 2020

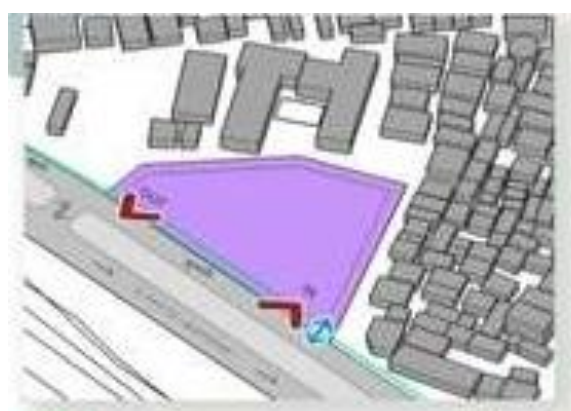

$\leftrightarrow$ Akses in sout sanki

Akses in 8 out Denghuri dan perigurting - Akoves pejalan kab

Gambar 17. Akses Keluar Masuk Tapak Sumber: Penulis, 2020

Pada tapak terdapat 3 akses menuju tapak, pada bagian muka terdapat 2 jalan, yaitu jalan kolektor (Prof. Dr. Latumenten) dan jalan lokal (dari pemukiman Semeru, Grogol), sedangkan dari sisi belakang tapak terdapat jalan masuk gang dari pemukiman warga Semeru, Grogol. Untuk akses keluar masuk pada tapak, dibuka menjadi 3 bagian, yaitu sisi kiri sebagai jalur keluar-masuk pejalan kaki dan sisi kanan sebagai jalur keluar masuk kendaraan maupun muatan besar. Untuk bagian belakang dibuka untuk akses pejalan kaki warga pemukiman Semeru, Grogol yang bekerja, belanja maupun menggunakan fasilitas pada bangunan.

\section{Analisis dan Konsep Pembentukan Massa}

Proses transformasi massa mengacu pendekatan lokalitas dengan mempertimbangkan bentuk tapak (segi tiga), kondisi lingkungan sekitar tapak, orientasi matahari, prinsip bukaan pengudaraan alami, analisis view dari dalam maupun luar tapak (antara lain dari jalan layang) dan akses keluar-masuk tapak.

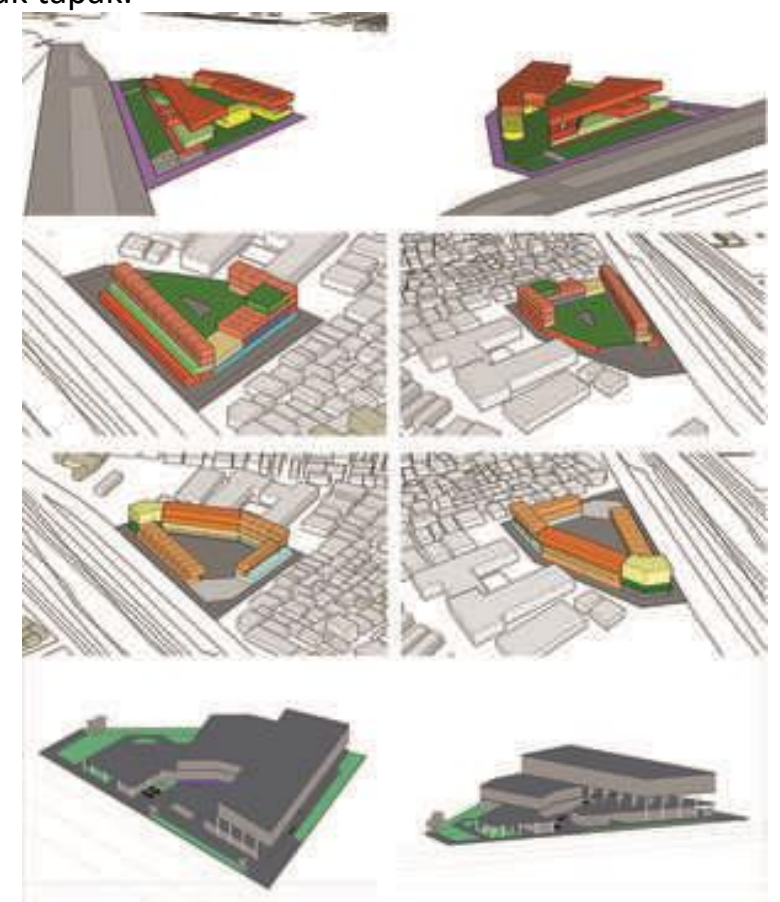

Gambar 18. Proses Transformasi Massa Sumber: Penulis, 2020 


\section{Analisis dan Konsep Perancangan Tapak}

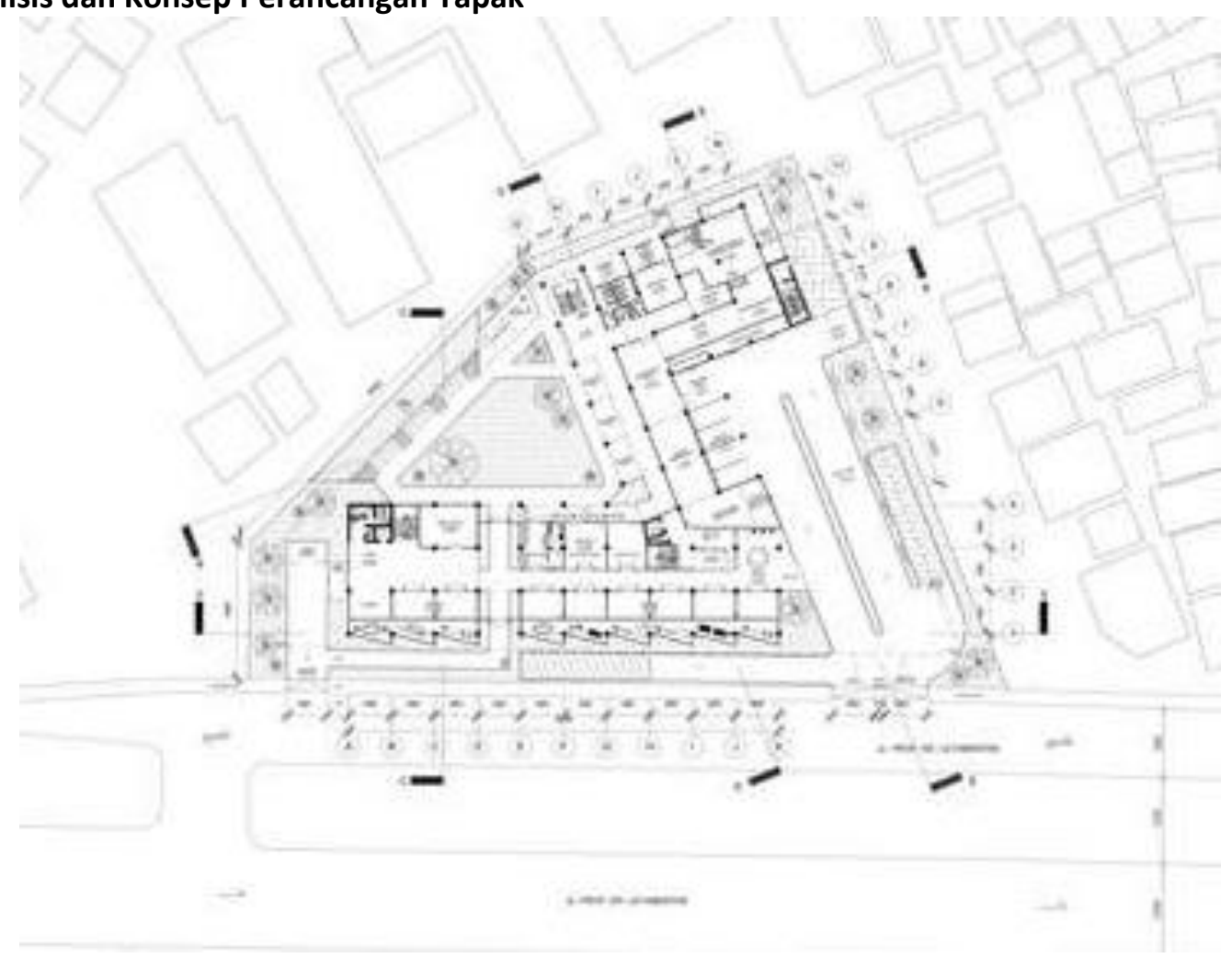

Gambar 19. Site Plan

Sumber: Penulis, 2020

Pengolahan site plan mempertimbangkan beberapa hal sebagai berikut: bentuk massa menyelaraskan dengan tapak yang berbentuk segitiga, sisi depan dimanfaatkan untuk jalur pedestrian dan deretan etalase/display produk (konsep windows shopping), aliran kendaraan dengan fasilitas drive-thru diarahkan melalui entrance kendaraan bermotor, dimana pengunjung bisa menggunakan aplikasi daring untuk pemesanan dan transaksi, kemudian bisa melakukan pengambilan sendiri ataupun memanfaatkan layanan antar barang.

\section{Analisis dan Konsep Penataan Zoning dalam Bangunan}

Metode Trans-programming yang diapikasikan tidak hanya pada sistem pendukung pada bangunan, namun juga secara susunan ruang baik vertikal maupun horizontal. Selain mengkombinasikan aspek lokalitas dan teknologi dalam keseharian, zonasi dalam bangunan juga dikombinasikan dengan memperhatikan keamanan, kenyamanan dan kebisingan pekerja, pengunjung dan penghuni. Seperti pada Gambar 19, zonasi horizontal terdapat ruang publik, kerja, komersil dan servis. Namun secara pengelompokan pengguna ruang, lantai dasar difokuskan zona publik sehingga tidak mengganggu ruang tinggal/hunian.

Area komunal berada di sudut belakang sebagai sentral berkumpulnya pengguna bangunan dan letak yang dapat diakses dari berbagai ruang. Untuk area kerja bersifat privat sehingga diletakkan pada bagian belakang agar sirkulasi pengunjung tidak terganggu. Kebisingan yang dihasilkan dalam proses kerja diatasi dengan perletakan ruang kerja di sisi belakang yang dilengkapi dengan dinding pelindung dan taman dengan vegetasi rapat. Pada bagian belakang juga terdapat area servis seperti kantin, musholla, koperasi dimaksudkan agar warga pemukiman Semeru, Grogol juga dapat menggunakan fasilitas yang ada, maupun membuka UKM makanan di ruang kantin. 


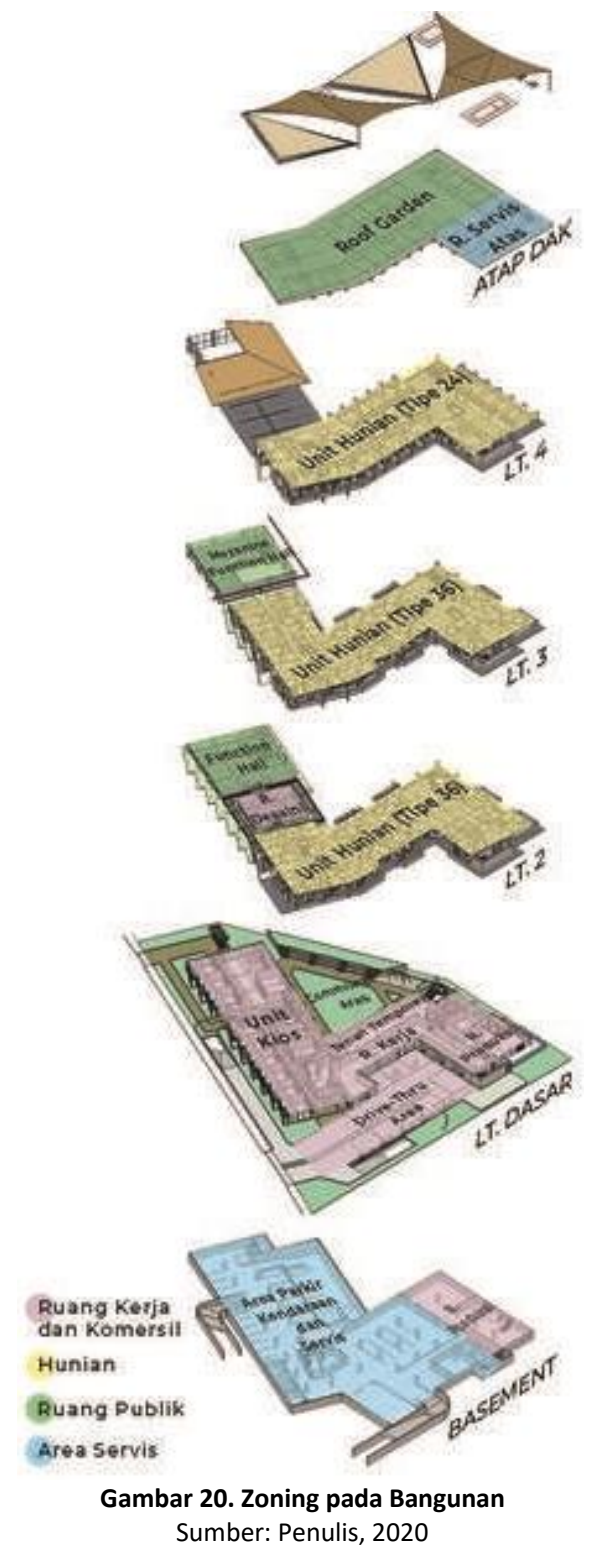

Pengaplikasian metode trans-programming yang mengkombinasikam jenis dan zona ruang di lantai lainnya dapat dilihat pada Gambar 20. Lantai dua terdapat unit-unit hunian yang berorientasi ke pemukiman Semeru dan bagian depan ke arah jalan layang, hunian diletakkan di atas level jalan karena tempat tinggal merupakan ruang yang membutuhkan privasi lebih. Ruang kerja berada satu lantai dengan hunian yang dapat diakses pengrajin yang tinggal di hunian, hal tersebut juga membentuk ruang fleksibel yang dibutuhkan oleh penggiat UKM, berupa ruang tinggal dengan ruang kerja. Sedangkan function hall yang bersifat publik pada lantai 2 diberi ruang transisi dengan ruang desain maupun hunian, untuk menjaga privacy penghuni.

Zona hunian berada di lantai 2 dan 3 bagi pengrajin yang sudah berkeluarga, pada lantai 4 diperuntukkan bagi bujangan. Di bagian atap digunakan untuk urban farming dengan sistem vertikultur, dan ruang bersantai khusus penghuni yang memiliki view di atas level jalan layang Tol Pluit-Tomang.

Lantai paling bawah, yaitu basement dikhususkan sebagian besar untuk area servis bangunan, parkir kendaraan, gudang, dan ruang kerja laser cutting. Ruang kerja di basement, dibuat lebih tinggi yaitu 4,5 m agar sirkulasi udara dari luar dapat tetap masuk, dapat dilihat pada Gambar 21. 


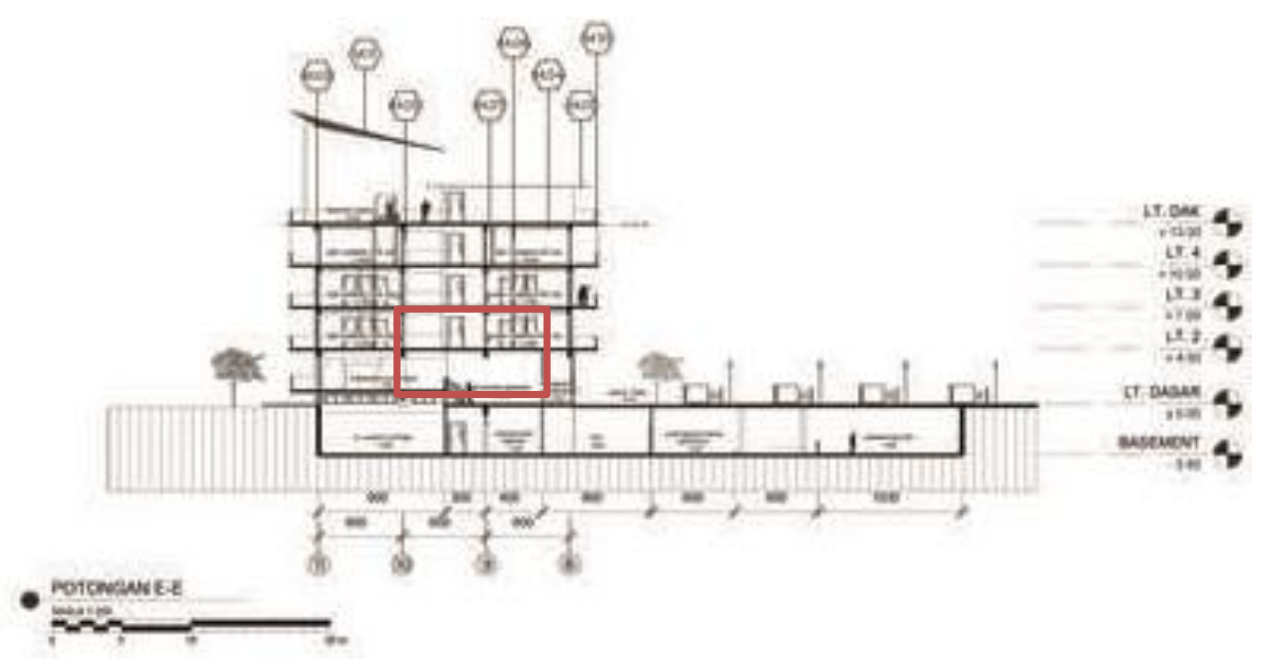

Gambar 21. Potongan E-E Bangunan

Sumber: Penulis, 2020

Untuk akses vertikal pada bangunan disediakan tangga dan lift. Untuk pengunjung disediakan tangga dan lift khusus yang hanya dapat diakses pada bagian Lobby 1 menuju function hall, sedangkan terdapat 2 tangga untuk penghuni menuju hunian dengan akses terjaga. Terdapat 1 lift untuk penghuni dikhususkan untuk lansia, servis maupun muatan barang berukuran besar. Terdapat pula 3 akses tangga kebakaran untuk kemanan penghuni selain di lantai dasar yang langsung mengarah ke ruang luar.

\section{Detail dan Fasad Bangunan}

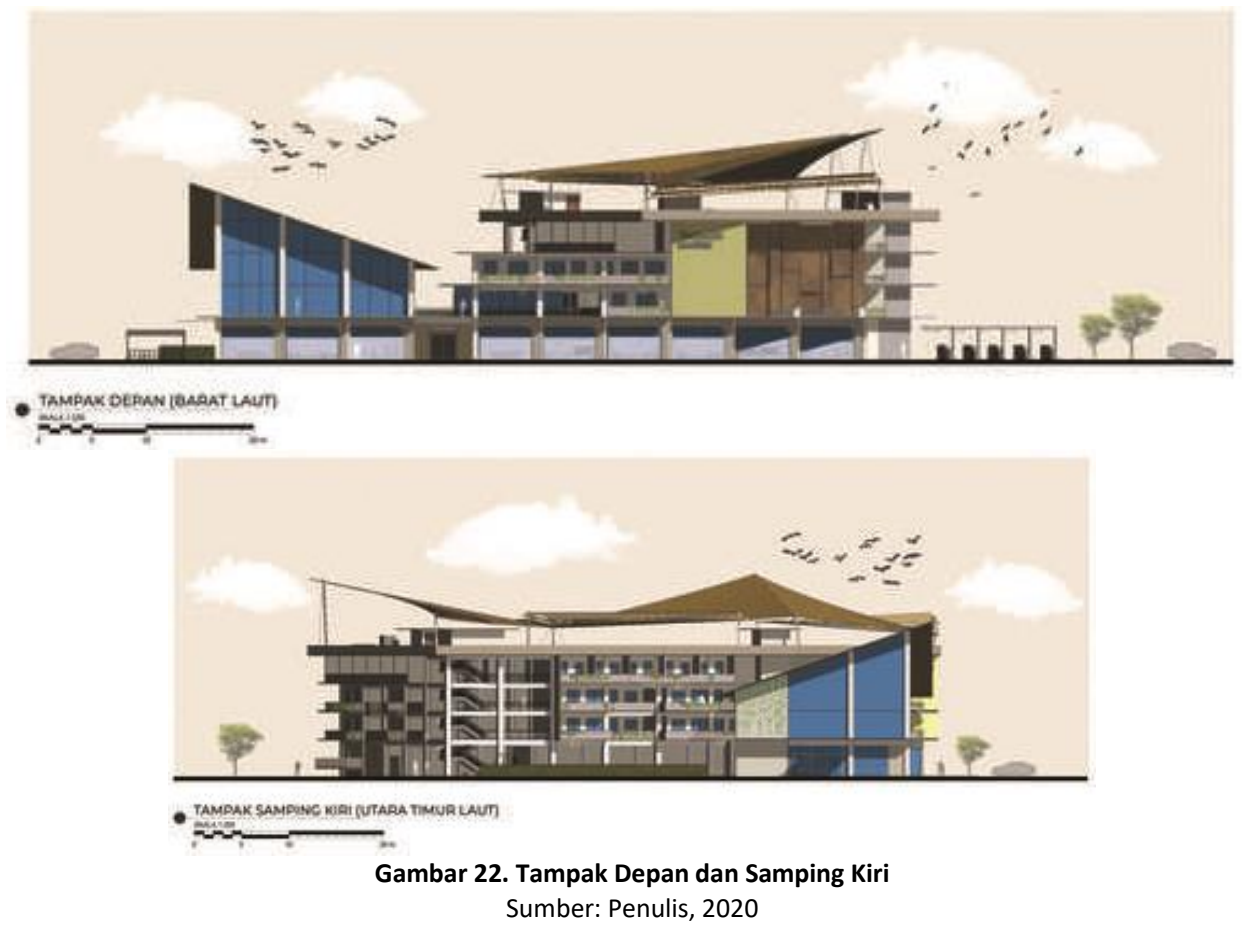

Desain tidak hanya mementingkan ruang dalam namun juga penampilan luar bangunan. Sehingga penggunaan struktur tenda pada bagian roof garden dan fasad anyaman rotan pada bagian depan bangunan untuk menambah estetika bangunan. Selain itu agar bangunan lebih interaktif, adanya permainan tinggi-rendah struktur tenda dan bentuk menjulang pada atap function hall menjadi daya tarik bentuk bangunan karena adanya jalan layang yang berada di depan lokasi perancangan. 

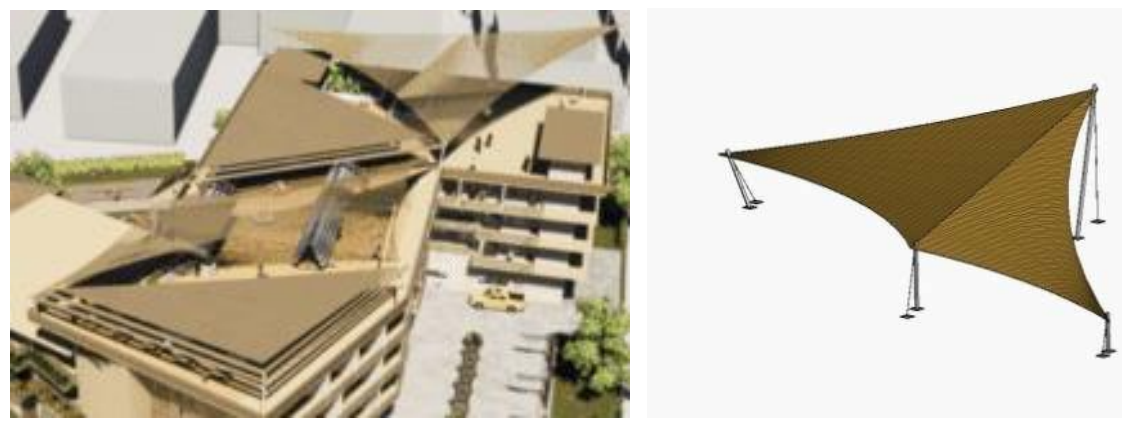

Gambar 23. Detail Stuktur Tenda Motif Rotan

Sumber: Penulis, 2020
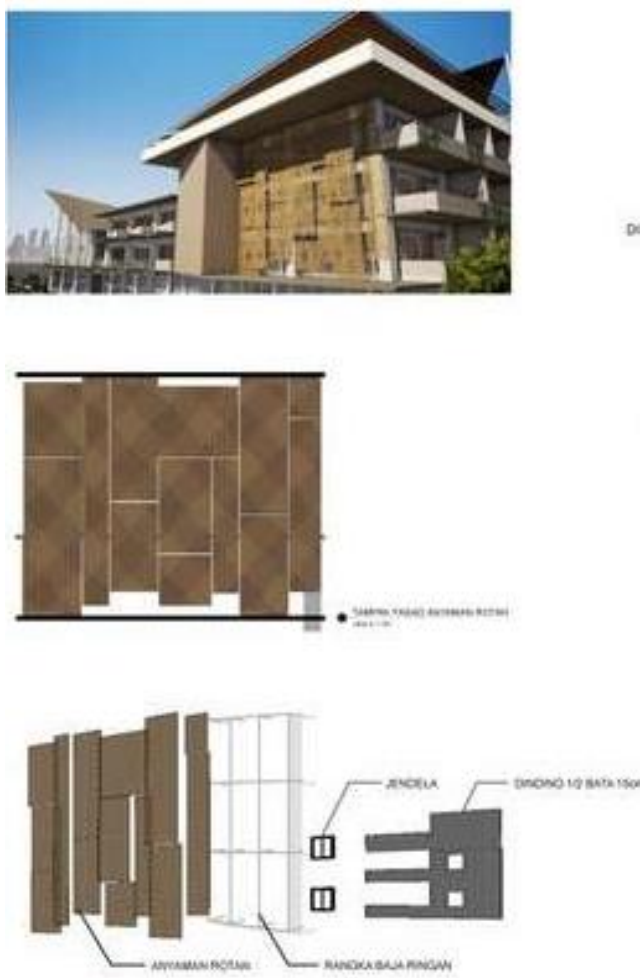

Gambar 24. Detail Fasad Anyaman Rotan Sumber: Penulis, 2020

\section{KESIMPULAN DAN SARAN Kesimpulan}

Kemampuan penggiat UKM Rotan dapat ditingkatkan terutama oleh generasi penerus yang telah melek teknologi dan memiliki inovasi tinggi dalam mengembangkan usaha lebih luas, seperti menggunakan teknologi dan media internet. Konsep yang tepat untuk usaha konvensional di era moderen tentunya harus memiliki unsur adaptif, fleksibel, dan tangguh agar dapat bertahan di segala kondisi tak terduga, maka dibutuhkan hunian terpadu yang dapat mengkombinasikan unsur-unsur tersebut. Proses desain dengan metode trans-programming dilakukan untuk memadukan aspek lokalitas dan kondisi keseharian yang terpengaruh oleh kemajuan globalisasi tersebut berupa kombinasi suatu ruang tinggal sekaligus ruang kerja. Pengaplikasian aspek lokalitas pada ruang melalui unsur material, adanya ruang produksi manual, kehidupan bertetangga, dan bersosialisasi. Adapun aspek teknologi pada bangunan menghasilkan ruang komersil moderen seperti kios-kios berupa windows shopping, proses jual beli drive-thru dan secara daring. Hal ini agar dapat mensejahterakan anggota komunitasnya. 


\section{Saran}

Maka hal-hal yang harus diperhatikan ketika merancang hunian dengan tempat kerja antara lain peletakkan ruang yang memperhatikan segala aspek seperti kebisingan, kelompok pengguna, demi kenyamanan pengguna, akses yang disesuaikan terhadap target agar mempermudah pengguna serta kemanan penghuni, dan juga memperhatikan sifat dari jenis ruang yang ingin digabung/dipadukan, baik dari zonasi, pengguna, maupun kebutuhan ruang itu sendiri.

\section{REFERENSI}

Badan Pusat Statistik Indonesia. (2020). Ekonomi Indonesia Triwulan III 2020. Diakses Desember 2020 dari https://www.bps.go.id/

Brodjonegoro, B. (2020, 14 Agustus). UMKM 4.0. Harian Kompas, hal. 6.

Chilnady, A. \& Febrian, Y. (2017). Theory of Contemporary Achitecture, Bernard Tschumi. Jakarta: Podomoro University Batch 3.

Jakarta Satu, Dinas Cipta Karya Tata Ruang dan Pertanahan DKI Jakarta. (2018). Peta Zonasi Kawasan Grogol. Diambil dari Jakartasatu.jakarta.go.id.

National Center for Immunization and Respiratory Diseases (NCIRD), Division of Viral Diseases. (2020). Center for Disease Control and Prevention: Social Distancing. Diakses 17 Agustus 2020 dari https://www.cdc.gov/coronavirus/2019-ncov/prevent-gettingsick/social-distancing.html

Portal Data Terpadu Pemprov DKI Jakarta, Dinas Perindustrian, Perdagangan, Koperasi dan Usaha Kecil Menengah. (2015). Daftar Sentra Industri Kecil dan Menengah Tahun 2014. Diakses Agustus/September 2020 dari https://data.jakarta.go.id/dataset/daftarsentra-industri-kecil-dan-menengah/resource/6465e1d6-1f77-46ec-ae6145b1302cab58

Shidfar, S. (2013). The Difference Between Dwelling and Home in Architecture. IJCSI International Journal of Computer Science Issues. 10(4)2, pp. 239-243.

Sutanto, A. (2020). Peta Metode Design. Jakarta: Jurusan Arsitektur dan Perencanaan, Universitas Tarumanagara

Veronica, M. (Juli, 2020). The Future of Dwelling. Kuliah Tamu TGA 8.30 UNTAR, Jakarta.

Wallpaper, Architecture. (2020). Architecture Seeks Designs for A Post-Pandemic World. Diakses $\quad$ Agustus/September 2020 dari https://www.wallpaper.com/architecture/global-post-pandemic-architectureresponses\#0_pic 1 